\title{
2010년 KOICA 무상 ODA 잠정통계 분석
}

\author{
고 요 한 KOICA ODA연구실 통계 전문관
}

\section{목차}

I. 잠정통계 개요

II. 2010년 우리나라 ODA 현황

III. KOICA ODA 실적 현황

N. 2010년 DAC 회원국의 잠정통계 주요 내용

V. 2010년 이후 원조 규모 예상

\section{I. 잠정통계 개요}

한국국제협력단은 정부 차원의 대외무상 개발협력 사업을 전담 실시하고 있는 정부출연기관으로 우리나라와 개발도상국과의 우호적인 협력 관계를 증진하고 이들 국가들의 경제 사회 발전을 지원함 으로써 국제개발협력을 증진하는 것을 목표로 하고 있다. 그리고 해마다 한국 수출입 은행을 통해, 공적개발원조 $(\mathrm{ODA})$ 또는 개발협력 실적을 1 년에 2 번, 잠정통계와 확정통계의 형태로 $\mathrm{OECD} \mathrm{DAC}$ (경제협력개발기구 개발원조위원회) 에 보고하고 있다. 지난 4월 6일 OECD DAC에서 2010년 DAC 회원국들의 ODA 실적에 대한 잠정통계 결과를 발표하였는바, 이에 근거하여 간단히 우리나라 2010년 $\mathrm{ODA}$ 실적과 $\mathrm{DAC}$ 회원국 실적을 살펴보고, 한국국제협력단의 $\mathrm{ODA}$ 실적을 $\mathrm{OECD} / \mathrm{DAC}$ 기준의 원조유 형별, 지역별, 소득수준별, 원조목적 코드별로 살펴보면서 분석. 정리해보고자 한다.

\section{2010년 우리나라 ODA 현황}

2010년 잠정통계 기준, 우리나라의 순 ODA 실적은 10 억 2천 6 백만 불로 (2009년 불변가격 및 환 율기준1) 전년 8억 천 6 백만 불 대비 $25.7 \%$ 증가하였다. 그러나 2010년 가격 및 환율 기준으로는 순 $\mathrm{ODA}$ 실적이 11 억 6천 8백만 불로 전년 대비 43.1\% 증가하여 2004-2005년 78\%, 2006-2007년 53\% 
에 이어 3 번째로 높은 증가율을 보였다. 또한 2010년 GNI 대비 ODA비율은 0.12\%으로 0.1\%였던 2009 년에 비해 $0.2 \%$ 포인트 상승 하였으나 2015년 GNI 대비 ODA 비율 $0.25 \%$ 의 목표를 달성하기 위해서는 앞으로도 더 많은 ODA 재원 확보가 필요한 실정이다.

\section{KOICA ODA 실적 현황}

\section{1. 총평}

$\mathrm{KOICA}$ 의 모든 ODA는 무상 (Grants) 이며 2010년 KOICA의 순 ODA 잠정 실적은 2010년 가격 및 환율기준 4 억 5 천 4 백만 불로 우리나라 순 ODA 실적 중 $38.8 \%$ 를 차지하였다. 이는 전년 KOICA 순 $\mathrm{ODA}$ 실적 2 억 7 천 6 백만 불 대비 $64.6 \%$ 증가한 금액이다.

\section{〈표 1〉2010년 OECD/DAC 순지출 ODA 잠정통계2)}

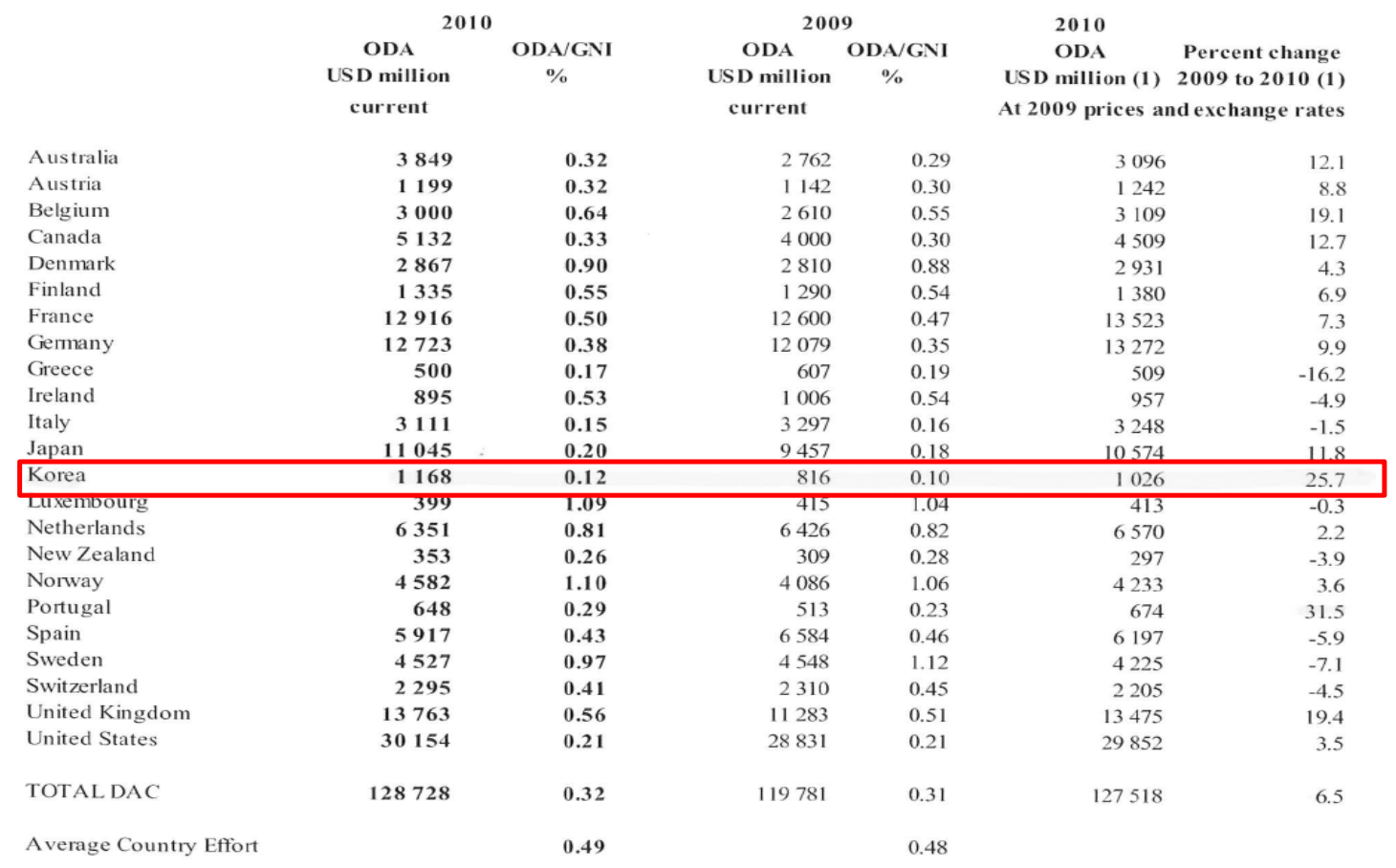

1) OECD DAC은 통계 작성을 위해서 매년 적용환율을 회원국에 통보하고 있으며 2009년 및 2010년 우리나라 적용환율은 $1,273.9$ 원 및 $1,155.4$ 원이다.

2) OECD, "Development aid reaches an historic high in 2010",

http://www.oecd.org/document/61/0,3746,en_2649_34447_47515235_1_1_1_1,00.html (검색일: 2011년 5월 1일) 
〈그림 1〉연도별 우리나라 ODA 지원 추이3)

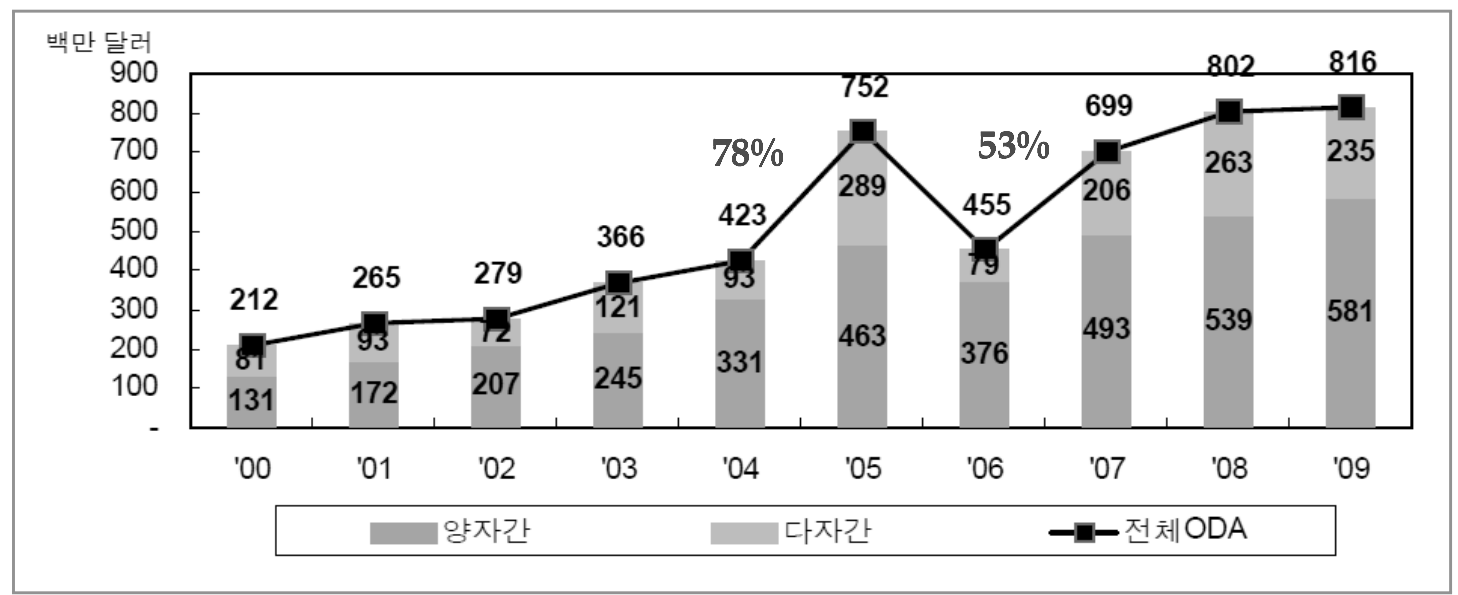

\section{2. 원조 유형별}

2009년에는 OECD DAC에 보고 하는 잠정 통계의 원조 유형이 프로젝트와 프로그램 원조, 기술협 력, 개발식량원조, 인도적 지원, 채무구제, NGO 지원, 국제 NGO 지원, PPP 지원, 개발인식 증진, 행정성 경비, 공여국내 난민지원, 그리고 기타 총 12 가지로 분류 되어 있었으나, 2010년 ODA 실적부 터는 원조 유형이 프로젝트(Project-type interventions), 전문가 및 기타기술협력 (Experts and other technical assistance), 공여국내 협력대상국 연수생 스칼러쉽 (Scholarships and student costs in donor counries), 채무구제(Debt relief), 예산지원 (Budget support), 기존의 NGO 지원, 국제 NGO 지원, PPP 지원을 하나로 묶은 국제기구 분담금, 공동 프로그램 및 자금 지원 (Core contributions and pooled programmes and funds), 행정성 경비(Admnistrative costs) 그리고 기 존의 개발인식증진과 공여국내 난민지원을 포함하는 기타 (other in-donor expenditures) 크게 8가 지로 새로이 분류되었다.

개발식량원조와 인도적지원은 2010년부터 원조유형의 하위 개념이 아닌 메모 아이템으로 따로 분류되어 보고하게 되었다.

3) 한국수출입은행, "2009 우리나라 ODA 확정통계 주요내용",

http://www.edcfkorea.go.kr/statistics/oda.jsp?st_code=6\&nd_code=8 (검색일:2011년 5월 1일) 
〈표 2〉 $2010 \mathrm{KOICA}$ 원조유형별 지원현황4)

\begin{tabular}{|c|c|c|c|}
\hline 원조유형 & 2010 지원액 (백만원) & 2010 지원액 (천달러) & 비중 \\
\hline 국제기구 분담금, 공동 프로그램 및 자금 지원 & 33,880 & 29,323 & $6.5 \%$ \\
\hline 프로젝트 & 274,267 & 237,378 & $52.3 \%$ \\
\hline 전문가 및 기타기술협력 & 149,137 & 129,078 & $28.4 \%$ \\
\hline 공여국내 협력대상국의 연수생 스칼러쉽 & 36,621 & 31,695 & $7.0 \%$ \\
\hline 행정비 & 25,740 & 22,278 & $4.9 \%$ \\
\hline 개발인식증진 & 5,072 & 4,389 & $1.0 \%$ \\
\hline 총계 & 524,716 & 454,142 & $100 \%$ \\
\hline
\end{tabular}

2010년 전체 KOICA ODA 잠정 실적에서 가장 큰 비중을 차지하는 원조유형은 프로젝트이다. 프로 젝트는 협력 대상국과 협의를 거쳐 정해진 사업 기간 내에 특정 지역에 확정된 예산을 가지고 설정된 목표를 달성하기 위해서 재원을 투입하고 사업 활동 진행하여 결과를 얻어내는 일련의 과정으로 이 루어진 원조 형태를 말한다. 2010년 KOICA는 전체 실적의 52.3\% (약 2억 3천 7백만불)을 프로젝트 형태로 협력대상국에 지원하였으며 $28.4 \%$ (약 1억 2천 9 백만불)를 전문가 및 기타기술협력의 형태로 지원하였다. 기술협력은 협력대상국의 역량 개발을 위해서 공여국이 지식 및 기술적 노하우을 전수 하는 지원형태로, 개발조사, 전문가 및 봉사단 파견, 그리고 역량개발에 초점을 둔 프로젝트가 여기 에 해당한다. 2009년에는 연수생 초청도 기술협력으로 구분하였으나 2010년부터는 독립적인 형태의 원조유형인 공여국내 협력대상국의 연수생 스칼러쉽으로 구분하고 있다. KOICA는 프로젝트와 전문 가 및 기타기술협력에 이어 이 스칼러쉽 원조유형에 $7 \%$, 국제기구 분담금, 공동 프로그램 및 자금 지원에 $6.5 \%$ 를 지원하였다.

2010년의 원조유형 구분이 2009년의 그것과 차이가 있기 때문에 KOICA의 2009년과 2010년 실적을 그대로 비교하기에는 어려움이 있으나 2009년 구분 기준으로 살펴보면 2010년 지원액 중 프로젝트 및 프로그램 원조로 지원된 금액은 총 2 억 3 천 5 백만 불로 전년 지원액 대비 $88.5 \%$ 의 큰 증가율 보였다. 이는 한국 정부의 아프가니스탄 지원 확대 약속에 따른 지방재건팀(Provincial Reconstruction Team) 규모 확대로 인하여 아프가니스탄의 지원이 크게 늘고, 기후 변화 대응 지원을 통하여 동아시아 지역 개발도상국의 빈곤감소와 MDG 목표 달성, 경제 성장, 에너지 안보를 목표로 하는 동아시아기후파트너 쉽 사업 실시에 기인한다. 2010년의 기술 협력은 전체 실적의 $35.4 \%$ 로 2009 년 $37 \%$ 에 비해 1.6 퍼센테 지 포인트 감소하였다. 그러나 금액으로 보면 2009년 1억 2백만 불에서 2010년에는 1억 6천만불로 $57.3 \%$ 로 증가했음을 알 수 있다. 기술 협력 지원비중이 2010년 감소로 나타난 이유는 2010년 KOICA

4) KOICA ODA 통계 시스템, 2010년 새로운 원조유형 기준임 
의 순 $\mathrm{ODA}$ 실적이 전년 대비 크게 증가하여 기술협력의 증가분이 전체 실적 증가분에 의해 상쇄되었기 때문으로 볼 수 있다.

〈표 3〉2009-2010 KOICA 원조유형별 지원현황5)

\begin{tabular}{l|r|r|r|r|c}
\hline \multicolumn{1}{c|}{ 원조유형 } & $\begin{array}{c}2010 \text { 지원액 } \\
\text { (천달러) }\end{array}$ & 비중 & $\begin{array}{c}2009 \text { 지원액 } \\
\text { (천달러) }\end{array}$ & 비중 & 증감 \\
\hline 프로젝트 및 프로그램 원조 & 235,381 & $51.8 \%$ & 124,899 & $45.3 \%$ & $88.5 \%$ \\
\hline 기술협력 & 160,557 & $35.4 \%$ & 102,091 & $37.0 \%$ & $57.3 \%$ \\
\hline NGOs 지원 & 10,345 & $2.3 \%$ & 7,369 & $2.7 \%$ & $40.4 \%$ \\
\hline 인도적지원 & 13,100 & $2.9 \%$ & 15,115 & $5.5 \%$ & $-13.3 \%$ \\
\hline 개발식량원조 & 2,879 & $0.6 \%$ & 66 & $0.0 \%$ & $4272.5 \%$ \\
\hline 행정비용 & 22,278 & $4.9 \%$ & 18,180 & $6.6 \%$ & $22.5 \%$ \\
\hline 개발인식증진 & 4,389 & $1.0 \%$ & 5,109 & $1.9 \%$ & $-14.1 \%$ \\
\hline 다자지원 & 5,214 & $1.1 \%$ & 3,098 & $1.1 \%$ & $68.3 \%$ \\
\hline & 454,142 & $100 \%$ & 275,928 & $100 \%$ & $64.6 \%$ \\
\hline
\end{tabular}

그리고 국내외 NGO 및 PPP 지원은 약 1천만 불로 2009년 7백만 불 대비 40.4\% 증가하였다. 이 는 $\mathrm{NGO}$ 사업 지원 건수가 작년 보다 9 건 늘어남과 동시에 $\mathrm{NGO}$ 봉사단원에 대한 지원도 2009 년 149 명 지원에서 2010년 202명 지원으로 $36 \%$ 증가한 데 기인한다. 한편 지진, 홍수 등 자연재해 및 전쟁, 질병 발생 등의 긴급 상황이 발생하였을 때, 사람의 생명을 구하고, 고통을 줄이며, 인간의 존 엄성을 보호하기 위해 지원되는 인도적 지원(Humanitarian Aid)은 전년 대비 $13.3 \%$ 감소한 수준인 약 1 천 3 백만 불이 지원되었다. 주로 재난 방지 및 예방, 재난 지역의 주민들의 편의 보호 및 정상적 인 일상으로의 복귀를 위한 피난처, 음식, 식수, 위생, 보건서비스 제공, 분쟁지역의 민간인들에게 안전과 복지 제공, 분쟁지역의 재건 등이 인도적 지원에 포함된다. 반면 개발식량원조는 전년 대비 $4672.5 \%$ 가 증가한 약 3 백만 불이 세계식량계획 (WFP)를 통해서 네팔, 라오스 및 아프리카 사하라 이남 지역에 지원되었다. 행정비용은 전년대비 약 $22.5 \%$ 가 증가하였는데 이는 전반적인 KOICA $\mathrm{ODA}$ 사업 확대로 인한 것이라 볼 수 있다.

\section{3. 지역별}

2010년 KOICA ODA가 가장 많이 지원된 지역은 아시아 지역이다. 전체 실적의 $64 \%$ 를 차지한 아 시아 지역은 2009년 53\%을 차지했던 비중이 11 퍼센테지 포인트 증가하였고 증가율로 보면 전년대

5) 수출입은행 통계 사이트, KOICA ODA 통계 시스템, 2009년 원조유형 기준임 
비 약 $100 \%$ 가까이 증가하였다. 이는 앞서 애기했던 것처럼 한국 정부의 아프가니스탄 지원 확대 약 속에 따른 지원액 확대와, 동아시아기후파트너쉽 사업 실시로 인하여 아시아 지역의 지원액이 큰 폭으 로 늘어났기 때문이다. 아시아에 이어 아프리카에 전체 KOICA 실적의 $17.6 \%$ 가 지원되었으며, 중남미 에 $10.7 \%$ 가 지원되었다. 아시아를 제외한 나머지 지역들은 전체 실적에 대한 비중이 2009년의 대비 크게 차이가 나지 않지만 금액을 비교해 보면 2010년의 각 지역의 지원액이 전년 대비 적게는 $46.6 \%$ 에서 많게는 92.1\%까지 증가되었음을 알 수 있다. 다자간 원조는 2009년 약 3 백만불에서 2010년 약 5 백만불로 약 $63.8 \%$ 증가하였으나 전체 실적 대비 차지하는 비중은 2009년과 2010년 모두 $1.1 \%$ 수준 으로 동일하였다. 아프리카 지역의 경우에는 사하라 이남 지역에 전체 아프리카 지원액의 $81.2 \%$ 인 약 6 천 5 백만불이 지원되어 2009 년 지원 실적 4 천 2 백만불 대비 약 $54.8 \%$ 가 증가하였다.

〈표 4〉2009-2010 KOICA 지역별 지원현황6)

\begin{tabular}{|c|c|c|c|c|c|}
\hline 지역 & $\begin{array}{c}2010 \text { 지원액 } \\
\text { (천달러) }\end{array}$ & 비중 & $\begin{array}{c}2009 \text { 지원액 } \\
\text { (천달러) }\end{array}$ & 비중 & 증감 \\
\hline 아시아 & 290,502 & $64.0 \%$ & 145,742 & $52.8 \%$ & $99.3 \%$ \\
\hline 아프리카 & 79,857 & $17.6 \%$ & 54,484 & $19.7 \%$ & $46.6 \%$ \\
\hline 아메리카 & 48,404 & $10.7 \%$ & 26,917 & $9.8 \%$ & $79.8 \%$ \\
\hline 오세아니아 & 2,458 & $0.5 \%$ & 1,279 & $0.5 \%$ & $92.1 \%$ \\
\hline 유럽 & 1,041 & $0.2 \%$ & 4,353 & $1.6 \%$ & $-76.1 \%$ \\
\hline 지역 미분류 & 26,667 & $5.9 \%$ & 40,054 & $14.5 \%$ & $-33.4 \%$ \\
\hline 다자 & 5,214 & $1.1 \%$ & 3,098 & $1.1 \%$ & $68.3 \%$ \\
\hline 총계 & 454,142 & $100 \%$ & 275,928 & $100 \%$ & $64.6 \%$ \\
\hline
\end{tabular}

〈표 5〉2009-2010 KOICA 사하라 이남 지역 지원현황7)

\begin{tabular}{l|c|c|c}
\hline & 2010 지원액 (천달러) & 2009 지원액 (천달러) & 증감 \\
\hline 사하라 이남 & 64,850 & 41,900 & $54.8 \%$ \\
\hline 아프리카 총지원액 대비 비중 & $81.2 \%$ & $76.9 \%$ & \\
\hline
\end{tabular}

\section{4. 소득그룹별}

소득그룹별로 지원 실적을 살펴보면 $\mathrm{OECD/DAC}$ 기준 최빈개도국(Least Devleopmed Countries) 에 지원한 금액은 약 1 억 8 천 5 백만불로 전체 실적의 $40.7 \%$ 차지하였다. 이는 전년 비중 대비 13.3

6) 수출입은행 통계 사이트, KOICA ODA 통계 시스템

7) 수출입은행 통계 사이트, KOICA ODA 통계 시스템 
페센테지 포인트 증가한 금액으로 MDG 달성 여부에 크게 영향을 미치는 국가들에 집중 지원 하고 있음 을 알 수 있다. 이어 저소득국(Low Income Countries), 하위중소득국(Lower Middle Income Countries), 상위중소득국 (Upper Middle Income Countries)에 각각 18.7\%, 30.5\%, 0.8\%을 지원하였다. 하위 중소득국에 대한 지원 비중이 저소득국에 대한 지원 비중보다 높은 이유는 저소득국으로 분류된 나 라는 총 12 국가, 하위중소득국으로 분류된 나라는 총 48 국가로 각 그룹의 국가 수에서 차이가 있었 고, 그 소득그룹에는 KOICA 평화 구축 사업이 진행되고 있는 이라크와 팔레스타인 및 지원 규모 상 위 10 대 수원국 중 5 개 국가(몽골, 필리핀, 인도네시아, 파라과이, 스리랑카)가 포함되어 있기 때문 이다. 2009년 지원 실적과 비교해 보면 최빈개도국, 저소득국, 하위중소득국 대한 지원액은 각각 $144.6 \%, 130.6 \%, 42.2 \%$, 증가한 반면, 상위중소득국과 소득미배분의 지원은 각각 $65.4 \%, 30.3 \%$ 감 소하였다.

〈표 6〉2009-2010 KOICA 소득그룹별 지원현황8)

\begin{tabular}{l|r|r|r|r|r}
\hline \multicolumn{1}{|c|}{ 소득그룹 } & $\begin{array}{c}2010 \text { 지원액 } \\
\text { (천달러) }\end{array}$ & 비중 & $\begin{array}{c}2009 \text { 지원액 } \\
\text { (천달러) }\end{array}$ & 비중 & 증감 \\
\hline 최빈개도국 & 185,005 & $40.7 \%$ & 75,646 & $27.4 \%$ & $144.6 \%$ \\
\hline 저소득국 & 85,056 & $18.7 \%$ & 36,892 & $13.4 \%$ & $130.6 \%$ \\
\hline 하위중소득국 & 138,473 & $30.5 \%$ & 97,357 & $35.3 \%$ & $42.2 \%$ \\
\hline 상위중소득국 & 3,410 & $0.8 \%$ & 9,844 & $3.6 \%$ & $-65.4 \%$ \\
\hline 소득 미배분 & 36,984 & $8.1 \%$ & 53,091 & $19.2 \%$ & $-30.3 \%$ \\
\hline 다자 & 5,214 & $1.1 \%$ & 3,098 & $1.1 \%$ & $68.3 \%$ \\
\hline & 454,142 & $100 \%$ & 275,928 & $100 \%$ & $64.6 \%$ \\
\hline
\end{tabular}

\section{4. 원조 목적 코드 (CRS Purpose Code)별}

2010년 KOICA ODA 지원 실적을 원조 목적 코드별로 구분해 보면 교육을 위한 지원이 $17.3 \%$ 로 가 장 높았으며, 그 다음은 다 부문 원조가 $16.8 \%$ 를 차지하였다. 이는 2010년 KOICA ODA 지원 실적의 $23 \%$ 가까이 차지하는 대 아프가니스탄 지원이 특정 섹타의 지원이라기보다 지방재건을 위한 다양한 부문에서 통합적인 원조 형태를 띠어 다 부문 원조로 구분되기 때문이다. 세 번째로 높은 지원 실적 을 보인 분야는 보건 부분으로 전체 실적의 $14.7 \%$ 를 차지하였고 그 뒤를 이어 통신 (7.5\%), 에너지 개발 및 공급(6.6\%), 식수 공급 및 위생(4.8\%), 농업(4.5\%)이 $5 \%$ 내외의 지원 비중을 보였다.

8) 수출입은행 통계 사이트, KOICA ODA 통계 시스템 
2009년 실적과 비교해 보면 가장 큰 증가율을 보인 분야는 재건구호로 2009 년 5 만 천불에서 2010년 약 1 백 4 십만 불로 증가하여 $2591 \%$ 증가율을 보였다. 그 다음 높은 증가율을 보인 분야는 다 부문 원조 로 2009년 대비 $729 \%$ 증가하였는데 이는 앞서 말한 대 아프가니스탄 지원 실적의 증가로 인한 것이다. 에너지 개발 및 공급 분야는 2009년 3백 7십만 불에서 2010년 2천 9백 7십만 불로 718\% 증가율을 보 였으며, 이밖에도 운송 및 창고, 금융 및 재무 서비스, 광물자원 및 광업, 건설, 임업,환경 분야에 대한 지원이 큰 증가율을 보였다. 그러나 물자원조 및 일반프로그램 지원, 재난방지 및 대비, 통상정책 및 규정, 무역조정, 관광 등의 분야에 대한 지원은 감소하는 모습을 보였다. NGO 지원은 2010년부터 CRS 목적 코드로 분류하지 않게 되어 목록에서 삭제되어 지원액 감소로 나타나게 되었다.

〈표 7〉2009-2010 KOICA 원조목적코드별 지원현황9)

\begin{tabular}{|c|c|c|c|c|c|}
\hline 원조목적 & $\begin{array}{c}2010 \\
\text { 지원액 } \\
\text { (천달러) }\end{array}$ & 비중 & $\begin{array}{c}2009 \\
\text { 지원액 } \\
\text { (천달러) }\end{array}$ & 비중 & 증감 \\
\hline 교육 & 78,382 & $17.3 \%$ & 46,911 & $17.0 \%$ & $67.1 \%$ \\
\hline 보건 & 66,766 & $14.7 \%$ & 51,437 & $18.6 \%$ & $29.8 \%$ \\
\hline 인구정책/시책 및 생식보건 & 4,016 & $0.9 \%$ & 3,340 & $1.2 \%$ & $20.2 \%$ \\
\hline 식수공급 및 위생 & 21,785 & $4.8 \%$ & 11,095 & $4.0 \%$ & $96.4 \%$ \\
\hline 공공행정 및 시민사회 & 15,910 & $3.5 \%$ & 22,283 & $8.1 \%$ & $-28.6 \%$ \\
\hline 기타 사회인프라 및 서비스 & 5,336 & $1.2 \%$ & 4,485 & $1.6 \%$ & $19.0 \%$ \\
\hline 운송 및 창고 & 8,684 & $1.9 \%$ & 4,040 & $1.5 \%$ & $115.0 \%$ \\
\hline 통신 & 34,231 & $7.5 \%$ & 29,001 & $10.5 \%$ & $18.0 \%$ \\
\hline 에너지 개발 및 공급 & 29,748 & $6.6 \%$ & 3,635 & $1.3 \%$ & $718.4 \%$ \\
\hline 금융 및 재무서비스 & 163 & $0.0 \%$ & 66 & $0.0 \%$ & $146.5 \%$ \\
\hline 비즈니스 및 기타 서비스 & 1,021 & $0.2 \%$ & 535 & $0.2 \%$ & $90.7 \%$ \\
\hline 농업 & 20,538 & $4.5 \%$ & 12,049 & $4.4 \%$ & $70.5 \%$ \\
\hline 임업 & 7,099 & $1.6 \%$ & 2,101 & $0.8 \%$ & $237.9 \%$ \\
\hline 어업 & 2,980 & $0.7 \%$ & 3,123 & $1.1 \%$ & $-4.6 \%$ \\
\hline 공업 & 10,715 & $2.4 \%$ & 11,245 & $4.1 \%$ & $-4.7 \%$ \\
\hline 광물자원 및 광업 & 1,109 & $0.2 \%$ & 355 & $0.1 \%$ & $212.2 \%$ \\
\hline 건설 & 614 & $0.1 \%$ & 121 & $0.0 \%$ & $405.6 \%$ \\
\hline 통상정책및 규정, 무역조정 & 1,259 & $0.3 \%$ & 3,408 & $1.2 \%$ & $-63.1 \%$ \\
\hline 관광 & 180 & $0.0 \%$ & 345 & $0.1 \%$ & $-47.8 \%$ \\
\hline
\end{tabular}

9) 수출입은행 통계 사이트, KOICA ODA 통계 시스템 


\begin{tabular}{|c|c|c|c|c|c|}
\hline 원조목적 & $\begin{array}{c}2010 \\
\text { 지원액 } \\
\text { (천달러) }\end{array}$ & 비중 & $\begin{array}{c}2009 \\
\text { 지원액 } \\
\text { (천달러) }\end{array}$ & 비중 & 증감 \\
\hline 환경 & 14,131 & $3.1 \%$ & 8,245 & $3.0 \%$ & $71.4 \%$ \\
\hline 다부문 & 76,083 & $16.8 \%$ & 9,172 & $3.3 \%$ & $729.5 \%$ \\
\hline 물자원조 및 일반 프로그램 지원 & 0 & $0.0 \%$ & 66 & $0.0 \%$ & $-100.0 \%$ \\
\hline 긴급구호 & 14,513 & $3.2 \%$ & 11,847 & $4.3 \%$ & $22.5 \%$ \\
\hline 재건구호 & 1,364 & $0.3 \%$ & 51 & $0.0 \%$ & $2591.1 \%$ \\
\hline 재난방지 및 대비 & 569 & $0.1 \%$ & 3,217 & $1.2 \%$ & $-82.3 \%$ \\
\hline 원조국 행정비용 & 22,278 & $4.9 \%$ & 18,180 & $6.6 \%$ & $22.5 \%$ \\
\hline NGO지원 & 0 & $0.0 \%$ & 7,369 & $2.7 \%$ & $-100.0 \%$ \\
\hline 비배분/비특정 & 9,455 & $2.1 \%$ & 5,109 & $1.9 \%$ & $85.0 \%$ \\
\hline 다자지원 & 5,214 & $1.1 \%$ & 3,098 & $1.1 \%$ & $68.3 \%$ \\
\hline 총계 & 454,142 & $100.0 \%$ & 275,928 & $100.0 \%$ & $64.6 \%$ \\
\hline
\end{tabular}

\section{2010년 DAC 회원국의 잠정통계 주요 내용}

\section{1. 총평}

2010년 OECD/DAC의 순 ODA 지원 실적은 1,287 억불(2010년 환율 및 가격기준)로 2009 년 1,198 억불 대비 $7.4 \%$ 증가하여 역대 최고의 실적을 보였으나, 환율효과 및 물가상승률을 제한 2009년 불 변가격 기준 실적은 1,275 억불로 전년대비 $6.5 \%$ 증가한 것으로 나타났다. 이는 채무구제와 인도적 지원을 제외한 양자간 프로그램 및 프로젝트에 대한 지원이 전년대비 $5.9 \%$ 증가함과 동시에, 양허성 차관이 전년 대비 $13.2 \%$ 증가한 데서 기인하고 있다. DAC 회원국 평균 GNI대비 ODA 비율은 0.32\% 으로 전년대비 $0.1 \%$ 포인트 상승하였으나 아직 유엔 목표인 $0.7 \%$ 에는 미치지 못하는 수준으로 나타 나고 있다. 아프리카에 대한 ODA 지원 실적은 293 억불, 이중 사하라 이남 지역의 지원액은 265 억불 로 실질 기준 전년 대비 각각 $3.6 \%, 6.4 \%$ 증가하였지만, 채무구제를 제외하면 실적이 아프리카 지역 은 $0.1 \%$ 감소, 사하라 이남지역은 $1.7 \%$ 증가하여 $\mathrm{MDG}$ 목표 달성을 위해 여전히 $\mathrm{ODA}$ 재원 확대가 필요함을 보여주고 있다. 
〈표 8〉2010년 OECD/DAC 순지출 ODA 잠정통계10)

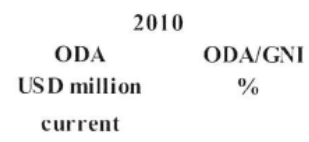

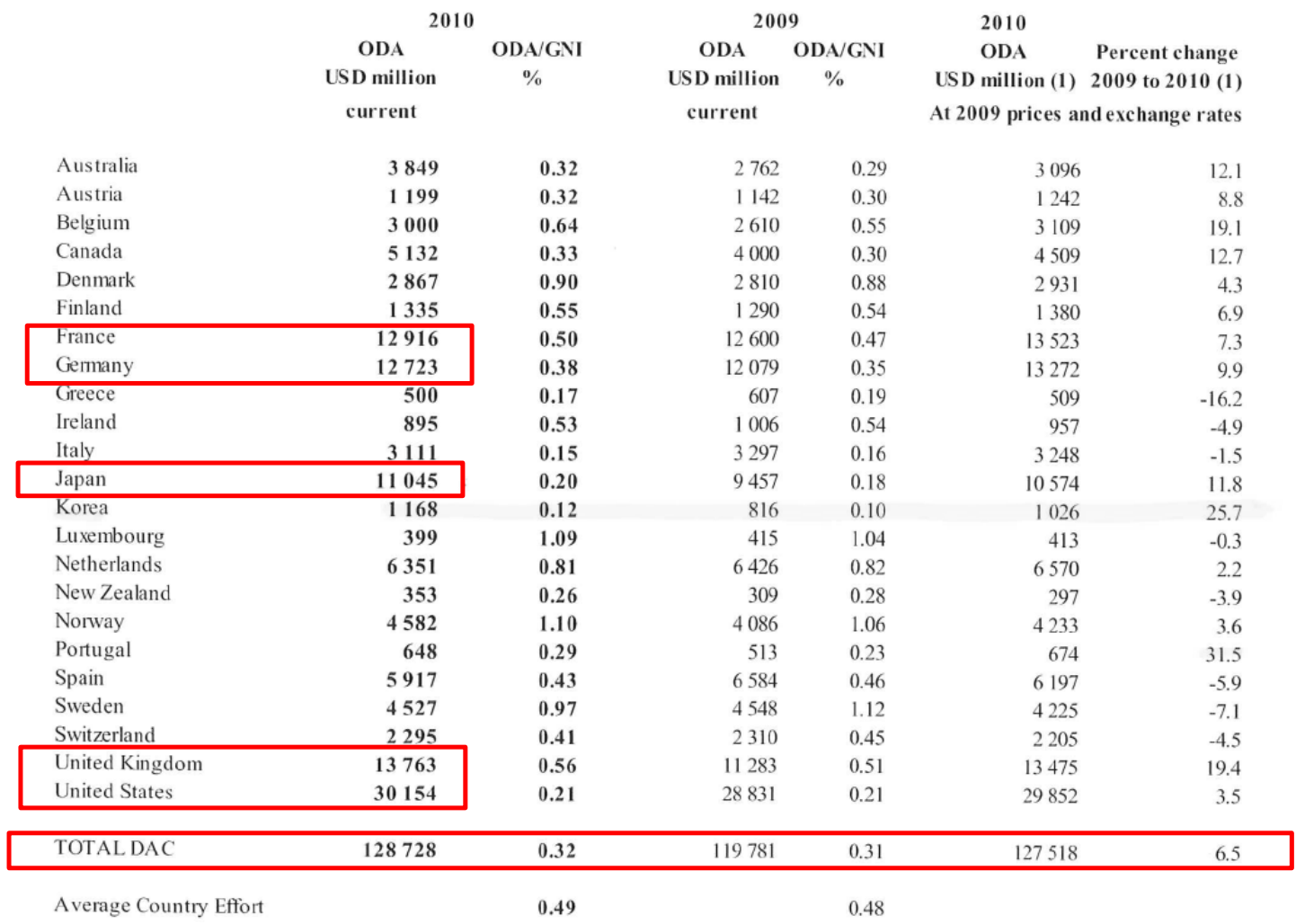

\section{2. $\mathrm{DAC}$ 회원국별 $\mathrm{ODA}$ 지원 현황}

$\mathrm{OECD} / \mathrm{DAC}$ 회원국 중 2010년 순 $\mathrm{ODA}$ 지원 규모(명목기준)가 가장 큰 5 대 공여국은 순위에서의 차이만 있을 뿐 전년과 마찬가지로 미국(301.5억불), 영국(137.6억불), 프랑스(129.2억불), 독일 (127.2억불) 그리고 일본(110.5억불)으로 나타났다. 전년에 이어 올해도 덴마크, 룩셈부르크, 네덜란 드, 노르웨이, 스웨덴은 유엔 목표인 GNI대비 ODA 비율 0.7\%을 초과 달성하였다. 그러나 2009년 불변가격 기준 전년대비 순 $\mathrm{ODA}$ 실적의 가장 큰 증가율을 보인 $\mathrm{DAC}$ 회원국은 우리나라(25.7\%)에 이어 포르투칼(31.5\%), 영국(19.4\%), 벨기에(19.1\%), 캐나다(12.7\%), 호주(12.1\%), 일본(11.8\%)으로 나타났다. 국가별로 증가율에 대한 세부 요인을 살펴보면 포르투칼은 양허성 차관의 증가, 우리나라 와 영국은 ODA 재원의 지속적인 확대, 벨기에는 채무구제와 양자간 지원의 증가, 캐나다는 세계은행 에 대한 지원과 양자간 지원의 증가, 호주는 최빈국에 대한 지원 증가, 일본은 세계은행에 대한 지원

10) OECD, "Development aid reaches an historic high in 2010",

http://www.oecd.org/document/61/0,3746,en_2649_34447_47515235_1_1_1_1,00.html (검색일: 2011년 5월 1일) 
과 최빈국에 대한 양자간 지원의 증가로 인한 것으로 나타났다.

미국은 순 ODA 지원 규모가 가장 큰 공여국으로 2010년 301.5억불(명목기준)을 기록하여 전년대 비 실질 기준으로 $3.5 \%$ 증가하였으나 GNI대비 $\mathrm{ODA}$ 비율은 전년과 동일한 $0.21 \%$ 을 나타냈다. 최빈 국에 대한 미국의 양자간 원조는 전년대비 $16.2 \%$ 증가한 94 억불을 기록하였는데 이는 대부분 2010 아이티 대지진에 대한 인도적 지원 때문인 것으로 나타났다. 최빈국 이외의 국가에 대한 지원 중 눈 에 띄는 것은 파키스탄에 대한 지원으로 전년대비 $126 \%$ 증가한 14 억불을 지원한 것으로 집계되었다.

$\mathrm{EU}$ 국가들의 순 $\mathrm{ODA}$ 규모는 2010년 702억불(명목기준)로 OECD/DAC 전체 순 $\mathrm{ODA}$ 지원액의 $54 \%$ 을 차지하였으며 전년 대비 실질 기준 $6.7 \%$ 증가하였다. GNI대비 EU국가의 평균 ODA 비율은 $0.46 \%$ 로 전년 대비 $0.02 \%$ 포인트 상승하였다. $\mathrm{EU}$ 국가의 중 경제위기를 겪은 그리스, 아일랜드 등 몇몇 나라를 제외하고는 대부분의 나라들이 양자간 무/유상 원조와 채무구제를 늘려 전년대비 ODA 지원 규모를 확대하였다.

\section{2005년 대비 지원 현황}

2005년 글렌이글스 (Gleneagles) G8 정상회의시 DAC 회원국은 ODA 확대를 위해여러 가지 목표 를 설정하였다. 각각의 목표에 대한 달성여부를 살펴보면, EU 15 개국 국가들은 2010년까지 GNI대비 $\mathrm{ODA}$ 비율을 $0.51 \%$ 까지 확대하기로 약속하였는데 이중 오스트리아, 독일, 그리스, 이태리, 포르투 갈, 스페인을 제외한 9 개 국가가 이 목표를 달성하였다. 미국은 2010 년까지 사하라이남 지역의 원조 를 2 배로 늘리기로 약속하였고 이 목표를 1년 앞선 2009년에 달성하였다. 2010년까지 ODA를 40억 불 (호주달러기준)까지 확대하기로 한 호주 또한 이 목표를 달성하였으며 GNI 대비 ODA 비율을 $1 \%$ 로 유지하겠다던 노르웨이와 $0.41 \%$ 까지 달성하겠다던 스위스 모두 이 목표를 달성하였다. 또한 2012-2013년까지 ODA 6억불 (뉴질랜드 달러)를 달성하겠다는 뉴질랜드의 목표 또한 무난히 달성할 것으로 보고 있다. 2005년 DAC 회원국이 아니었고 당시 어떤 목표도 설정하지 않았던 우리나라의 $\mathrm{ODA}$ 는 2005년부터 2010년까지 실질기준 56\% 증가하였다.

이와 같은 확대로 인하여 DAC 회원국들의 ODA 규모가 2004년 이후 실질기준으로 약 $37 \%$ 증가하 였으나 2005년에 공약당시 예상했던 2010년 ODA 규모과 비교했을 때는 약 190억불 모자라는 것으 로 나타났다. 이중 약 10 억불 정도가 경제 위기로 인하여 달성되지 못한 것으로 분석되었고 나머지 180 억불은 $\mathrm{ODA}$ 재원 확대를 공약했던 일부 회원국들의 그 목표를 달성하지 못하여 부족한 것으로 나타났다. 또한 글렌이글스 회의 에서 G8 공여국이 아프리카 지원액을 250 억불 확대하기로 약속하 였으나 현재까지 확인된 바에 의하면 확대된 금액은 110 억불에 불과했다. 이는 아프리카 최대 공여 국들 중 일부 국가들의 $\mathrm{ODA}$ 재원이 크게 줄어듦으로 인한 것으로 분석되었다. 


\section{2010년 이후 원조 규모 예상}

$\mathrm{OECD} / \mathrm{DAC}$ 는 2013년까지 ODA 규모가 얼마만큼 확대될지 각 회원국들을 대상으로 조사를 마쳤는 데 이에 따르면 원조 규모 증가가 느려질 것으로 예상되고 있다. CPA (인도적지원, 채구구제, 행정 성 경비 등 공여국내 비용을 제외한 모든 ODA)는 실질 기준 2011-2013년 사이 2\%정도 밖에 증가되 지 않을 것으로 보인다. 과거 3 년간 평균 $8 \%$ 의 증가율을 보인 것에 비하면 낮은 수치라고 하지 않을 수 없다. 이런 낮은 증가율은 과거 3 년 동안 평균 $13 \%$ 증가했던 지원액이 $1 \%$ 증가에 그칠 것으로 예 상되는 아프리카의 저소득국에서 특히 두드러지게 나타날 것으로 예상되고 있으며 아프리카 인구 증 가율을 따라갈 수 없어 원조의 효과가 상쇄될 것으로 보고 있다. DAC 회원국들이 자국의 공약을 성 공적으로 이행하고 MDG에 조금 더 가까이 다가서기 위해서는 다양한 개발재원 활용, 지속적인 원조 의 질 개선, 정책 일관성 제고, 다양한 개발 파트너쉽 확대가 중요할 것으로 보인다. 


\section{참고문헌}

1. OECD, "Development aid reaches an historic high in 2010",

http://www.oecd.org/document/61/0,3746,en_2649_34447_47515235_1_1_1_1,00.html（검색일:

2011년 5월 1일)

2. 한국수출입은행, "2009 우리나라 ODA 확정통계 주요내용”,

http://www.edcfkorea.go.kr/statistics/oda.jsp?st_code=6\&nd_code=8 (검색일:2011년 5월 1일) 